\title{
The elderly in the shopping centers: the usability study of semipublic spaces as attractiveness generator
}

\author{
Maria Cristina Bittencourt ${ }^{\mathrm{a}^{*}}$, Vera Lúcia Duarte do Valle Pereira, ${ }^{\mathrm{a}}$ Waldemar Pacheco Jr. ${ }^{\mathrm{a}}$ \\ ${ }^{a}$ Department of Prodution Engineering and Systems, Universidade Federal de Santa Catarina, Campus Trindade, \\ Florianópolis, SC, Brasil
}

\begin{abstract}
This article aims to study the importance of the attributes of usability and attractiveness for the semi-public spaces of Shopping Centers considering the elderly users, the psycho-cognitive and bio-physiological changes resulting from the aging process, as well as their expectations of the built space. Through a qualitative study of theoretical review with a multidisciplinary focus in architecture, ergonomics, gerontology, environmental psychology and management, the conditions of the elderly users were identified, and also the attributes related to usability and attractiveness, collected in order to understand and organize their interrelationships, to suggest recommendations about the drafting of Shopping Centers, aiming to generate projects and environments that should promote the efficient and satisfactory use for elderly and may also create a competitive advantage for these enterprises.
\end{abstract}

Keywords: elderly, usability, attractiveness, semipublic spaces, shopping centers

\section{Introduction}

The demographic curve transformation caused by increasing life expectancy worldwide and national, imposes increasingly implementing actions to improve the older people quality of life. To achieve this goal requires a greater depth studies in biological, psychological and social issues related to old age, that should not longer be considered as a limit to vitality, social participation and productivity.

There are now older people than young adults and adolescents in the world. This number may reach 2 billion in 2050, with $80 \%$ and they will be in developing countries [7]. This growth is due especially, among other factors, the medical sciences development and the new technologies acquisition, as well as cities urbanization improvement.

The spaces we use, open or closed, public or private, mediates these possibilities. It's necessary to identify and understand the determinants of relationship between the individual elderly and built environments in order to humanize and qualify spaces to effective use and access, to enhance performance, providing safety and satisfaction for these users.

Shopping malls, on the other hand, are adressed in several areas of knowleges and studies. Their spaces offer safety, confort, climate control and entertainment, generating many jobs and foreign exchange, and the semi-public spaces accommodates goods consumption and services, also leisure, meeting, social participation and integration. They are now more proportionately frequented by the elderly.

This paper presents an initial description of the process of aging and elderly and the environmental relationship, then the definitions and spaces usability sudies, focused on Shopping malls, their typologies and relating to the issue of attractiveness, of this semipublic spaces for elderly users, demonstrating the relationship between biological, phsyco-cognitive and social aspects the elderly and attributes of usability and attractiveness for Shoppings Centers spaces in general.

\footnotetext{
*Corresponding author. arqcrisb@gmail.com,

Rua Esteves Junior 458-Florianopolis-Brasil
} 


\section{Methodology}

This is a qualitative study from a theoretical review, by interdisciplinary approach between architecture, environmental psychology, gerontology, ergonomics, marketing and administration literature, from where, initially, three main general axes were defined: the physical, cognitive and social aspects, about the elderly and environment interrelationship $[1,9,14,32]$, the usability attributes categorized into physical or objective (functional organization, environmental comfort, accessibility and orientation) and the psychological, social or subjective aspects (security, identity, pleasantness with the environment) $[3,5,10,12,14,17,21,23,24,27,30,36$, $38,41]$ and generating attractiveness factors (activities, facilities, security, among others) $[14,31,35]$ to Shopping Centers spaces [50].

Through check-list and comparative analysis, the attributes were selected and rearranged in tables 1 and 2, generating a final table 3 of attributes, that shows the interdependence between the three axes defined, to the inner spaces of the shopping malls. Finally, recommendations are for qualifying them to be usefull, easily useble and attractive to the older adults.

\section{Theoretical review}

\subsection{The elder, concepts and definitions}

The elderly, are part of a group of individuals distinguished from each other under the socio-economic, demographic and epidemiological, which share common characteristics such as experience and wisdom.

Many are the ratings to determine how and when a person becomes "old", and this word can means "who has many years, old, senile" [31]. Such definitions should not be generalized, because not everyone who "has many years" have a body or feels "old" or has a "senile mind", or both.

According to WHO (World Health Organization), the age limit between the adult and the elderly is 65 years for developed nations and 60 years for developing countries. The United Nations (UN) see aging subdivision in four stages: middle age, corresponding to those between 45 and 59 years, the elderly between 60 and 74 years, the elderly, for people between 75 and 90 years, and extreme old age, acci-ma 90 years old [34].
Chronological age should not override the cultural work, recreation, and socializing possibilities, since according to several authors there is no exact age to determine the onset of old age, and "age cronological itself, is the useful a marker for behavioral changes" $[5]$.

The "senescence" which is the period marked by decline in body functioning, may vary according to the physical, social, environmental, and psychological [11], and the aging process occurs at different times and in different ways for each individual. $[5,11,40,53]$.

It is important at this stage to adopt an active life, with visits to sites to establish the connection of the elderly with the world through leisure and social activity, both for "maintaining functional capacity and well-being, as the self-update image and selfefficacy", which may depend on the environmental conditions that allow elderly perform adaptive behaviors [1].

In this sense, the environments can aid in the treatdure gives some demands of the elderly, helping security, independence, and satisfaction to goals achievement.

\subsubsection{The aging process, biological, psycho- cognitive and social changes.}

Aging should be treated as a natural process of human development, which evolves progressively [28]. Many problems resulting from aging and longevity are the result of lifestyle or disease, and can be classified into two stages: The primary results from the gradual deterioration of body throughout the life cycle, and the secondary as a consequence of disease, abuse, lack of use or factors that are under the people control. [12].

The aging process causes naturaly biological, physiological, and social changes $[15,19,43]$ that aggregate changes in daily routine, influencing the the elderly behavior by gradual decline in cardiorespiratory-dispositional, organic disorders, and changes in body $[15,19,43]$.

Disability is defined as the difficulty or impossibility on performancing of certain managements and activities of daily living and symptoms gauge, to the diseases or disabilities, cardio vascular systems, respiratory, endocrine, skeletal muscle and nervous.

With the functional changes, reductions in some capacity may directly interfere in the use of spaces, such as mobility and shifts in perception of temperature, reduced physical strength, propensity to falls, safety and environment awareness, readability, orientation in space $[45,46,53]$. 
Sensory changes relate to changes in the structures responsible for perception of environmental stimuli proveneientes (external receivers), and the interior of the body (internal receivers), which are are found in sense organs: skin, ear, eye, tongue, nasal passages, which in turn has the ability to transform stimuli into nerve impulses which are transmitted to the central nervous system, which determines the different reactions of our body.[42].

The changes in the sense of sight, hearing, taste, smell, touch and haptics, often interfere with the use of spaces causing changes: mobility, displacement, also in the identification, location, legibility and orientation in space, understanding of auditory information in the environment, feelings of insecurity, risk of accidents environments, temperature sensing $[11,43]$.

Cognitive changes are modifications in the set of mental abilities that allow the acquisition of new knowledge and the maintenance of information already acquired. It comprises a set of functions that are distinguished either by the characteristics of information to be processed (visual, verbal, mixed, differing from oral written language, visual perception of hearing) or by type of treatment to achieve (attention, memory, calculation). The memory impairment is related to the memory of recent events and past, and the organization-tion and uses the information stored [40, 42, 43, 45, 46].

Also the influence of demographic factors, social economic, cultural and psychosocial factors and the loss of this capability is the need to adapt to the new reality $[11,15,43]$.

The social aspect concerns the relations of the elderly to society, the financial changes and consequences, so in retirement. The work is a convenient source of social contact, so that retirees tend to reduce the impact $[14,15]$. Also the advancement of technology and capitalist society excludes people with advanced age of labor relations, social relations and peripherally, which can affect self-confidence, self-esteem, autonomy and independence for the elderly that are directly related $[14,15]$.

Losses associated with cognitive, emotional and psychic turbulence, can cause unhappiness, reducing the quality of life $[14,15]$. The elderly tend to change their habits for active little routines [19.30], causing a reduction in attention span, reaction and coordination that can hamper the performance of daily activities in a healthy way, producing apathy, self devaluation, lack of confidence the elderly and leading to isolation and loneliness [30].

There is a close relationship between environmental conditions and lifestyle of the people, and the physiological changes are not only order, but also result in eating habits and daily routine of physical activity.

So, improved over the study design of the built environment can enrich the spatial mobility, autonomy, self-efficacy and self-esteem may help the connection of elderly with the world through an active life and social participation in this important phase of lifeattend.

\subsection{Usability, concepts and definitions}

Usability relates to the built environment is still an unexplored field and there is little research on usability testing as a method of measurement used in the context of architectural design [47,52].

The term "usability" is informally defined as "the ease of using a particular product" [36] and formal classification proposed by the IEA (International Standard Organization) defines usability as "effectiveness-ability, efficiency and satisfaction with which specified users can achieve specific goals in particular environments" [20].

It means "to set the focus on the user, because their characteristics can determine the ease or difficulty in using a product or spaces [21].

In this context, the ergonomics of the built studied human interactions with the interior spaces of work, and leisure services, circulation, flow, signage and accessibility. Also of urban space, architectural barriers, bookmarks, spatial orientation and cognitive maps in the city, signage and accessibility [3].

\subsubsection{The various dimensions of usability}

Usability related to the environment can take several other concepts originated from the interrelationship between individual and physical spaces. Some more subjective, like "identity, affection, attachment to place, familiarity, satisfaction" $[12,22$, 27, 32, 37, 44, 48] conditions studied in architectural design and urbanism, and environmental assessments in psychology and gerontology.

The dimensions are more objective characteristics of the spaces themselves, as the function, environmental comfort, and factors such as lighting, temperature, ventilation, information, signage, and even physical access [28,39,44].

Related individuals are "learnability" that means how easy it is for users to accomplish basic tasks while using the spaces.

"Efficiency", is related to how quickly can the user perform tasks in the space and "memorability" means the proficiency reestablishement after a period of not 
using the space, and to reduce errors is related to how many and how severe the errors are and how they can easily recover from them. Finaly, the "satisfaction" is a very important factor to the elderly, related to how pleasant it is to use the space $[5,32]$.

The key one is "utility", which refers to the functionality corresponding to user needs [5, 32]. Also, the "aesthetic" is directly related to usability, the better aesthetics give a product more likely to be well understood and use, installation, or object correspond to its intended use, the user will have more ease and efficiency in use [38].

Usability will enhance quality of life, and even save lives. Thus, the design of spaces facing the elderly users grounded in the study of usability should consider prior knowledge about their characteristics and needs.

It means generating "efficiency" to minimize the effort to understand the use of spaces, the "effectiveness" to achieve the expected goal, and "satisfaction" for the elderly by increasing the level of comfort in using the spaces.

\subsection{Shopping Centers, definitions and typologies}

The shopping malls are places to trade leisure and sociability, whose appropriation of users is marked by cultural diversity of the universe and the type of use made [16]. They have become not only centers for shopping, but also community centers for social and recreational activities $[2,10,27,35,39,51]$ contributing to bring information, communication, culture and even to individuals in the geographic spread area [39].

The designs of these projects are conducted to a large population of users with varying consumption habits, and cultural behavior in the built environment $[6,8,35]$ and among them, the elderly.

There are several shopping malls such as the "traditional ones, with satellite stores that combine with anchor tenants, and attract a large flow of people, the "outlets" are composed by factory stores, or offprice, with a strategy of offering low prices to the consumer, and "thematic or specialized" retailers meet a segment such as fashion or decoration, and "festival malls" that are dedicated to cultural activities and entertainment [2,35].

The usability of shopping centers spaces, such as the environment in general, involves the analysis from the individual aspects related to the physical space, as well as specific characteristics of the environment itself.

Table 1 below shows the organization of objective and subjective attributes of usability, considering the user and physical space.

Table 1

Organization of subjective and objective attributes of usability

\begin{tabular}{|c|c|c|c|c|c|c|c|c|}
\hline \multicolumn{9}{|c|}{ Usability } \\
\hline \multicolumn{3}{|c|}{ Subjective attributes } & \multicolumn{6}{|c|}{ Objectives attributes } \\
\hline & & & & Accessibility & Guidance & Comfort & Functionality & Design \\
\hline 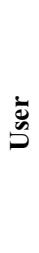 & $\begin{array}{l}\text { Learnability } \\
\text { Memorability } \\
\text { Fidelity } \\
\text { Patience } \\
\text { Identity } \\
\text { Familiarity } \\
\text { Affect } \\
\text { Motivation }\end{array}$ & $\begin{array}{l}\text { Satisfaction } \\
\text { Attachment to } \\
\text { place } \\
\text { Interaction } \\
\text { Security } \\
\text { Ease } \\
\text { Self-esteem } \\
\text { Self-efficacy }\end{array}$ & 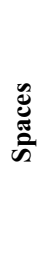 & $\begin{array}{l}\text { Physical Access } \\
\text { Circulation } \\
\text { Barriers } \\
\text { Flows } \\
\text {. }\end{array}$ & $\begin{array}{l}\text { Circulation } \\
\text { Information } \\
\text { Signaling }\end{array}$ & $\begin{array}{l}\text { Ventilation } \\
\text { Lighting } \\
\text { Temperature } \\
\text { Floors }\end{array}$ & $\begin{array}{l}\text { Utility } \\
\text { Effectiveness } \\
\text { Efficiency }\end{array}$ & Aesthetics \\
\hline
\end{tabular}

Assembly of the author. Source: Lynch, 1960, Hall, 1981, Tuan, 1982, Sommer, 1997, Bevan, 1995, Ornstein et. al, 1995, Preiser, 1998, Jordan, 1998, Del Rio, 2002, Rheingrantz, 2002, Moraes, 2004, Gunther, 2005, Coleman, 2006, Mallard, 2007, Afacan, 2009, Figueiredo, 2009, Fisk, 2009, Lidwel, Holden, Butler, 2003, ISODIS 9241-11. 


\subsubsection{Attractiveness of Shopping Centers semi-public spaces}

Semi-public spaces are considered the transition between the public and private $[4,18]$, and in the internal Shopping Centers, are the common areas enterprise, or movement, leisure, feeding, parking, toilets, and giving direct access to the public.

A shopping center is in its premise to make it all work well, it depends on this, so that your audience will feel comfortable and safe room [39], a factor noted in several surveys on the attractiveness of Shopping Centers and the influence of their environment on consumer behavior [13].

"Attractiveness" word means "the quality of what is attractive" and the concept in this case is related to attributes that have a higher degree of importance attached by consumers $[13,47]$ that may vary according to the consumer $[13,25]$. People goes to the mall shopping for your interest in and to satisfy various needs, and consumers who prefer to shop at the mall consider the comfort, convenience, safety, and practicality. Increasingly, retail centers, indoor or outdoor, large or small, themed or general are designed to resemble a comunity with more emphasis on recreation and other services and in its outcome on consumption [23].

In this competitive scenario it is crucial to narrow the approach with the customer care by analyzing data from their individual behavior and its peculiarities, to guide personalized actions about what customers think and valorize. Several authors examined the effect of mall physical envinonment on consumer emotional state and found that malls were viewed by consumers as a place not only for shopping, but to entertainment. However, still just a few studies analyses the motivational aspects of consumers that explain their attraction to shopping malls. They are attracted to economic or emotional motives, or a combination of both [27]. It was found that the diversity of environments created in Shopping has a direct effect on the length of stay and consumption on the client side $[13,23,25]$ and thus upgrades in functional terms and ambience to attract the diversity of users are a constat concern.

With the growing numbers of malls, shoppers tend to be more selective and is essential for mall menegers to know the extent to which their malls area become attractive to their shoppers [25]. People from different generations experience different stimuli relevant to the assessment of the atmosphere of the Shopping Center $[13,47,49]$.

The addition of cultural, health care, and medical clinics, diagnostic, physical rehabilitation, health clubs and related businesses, brings easy access for the elderly, which have become a kind of potential client of Shopping Centers. The research in developing a strategy for renewal of Shopping Centers may be more beneficial considering the different customer segments. [49]

Table 2 shows the organization for the user categories of attributes, collectes in the literature, such as: the psychological, functional and socio-economic as well as, the psychological, functional and socioeconomic, and those related to functionality, environment, spaces, activities and services offered by the shopping centers in general.

Table 2

Organization attributes of attractiveness for the user and spaces of Shopping Centers

\begin{tabular}{|c|c|c|c|c|c|c|c|}
\hline \multicolumn{2}{|c|}{$\begin{array}{l}\text { Psychological, } \\
\text { Funcional }\end{array}$} & \multirow{2}{*}{$\begin{array}{l}\text { Social, } \\
\text { Economics } \\
\text { Social proposal } \\
\text { Environmental } \\
\text { proposal } \\
\text { Economic motives }\end{array}$} & \multicolumn{2}{|c|}{$\begin{array}{l}\text { Space, } \\
\text { Functional }\end{array}$} & \multirow{2}{*}{$\begin{array}{l}\begin{array}{l}\text { Environment, } \\
\text { Atmosphere }\end{array} \\
\text { Diversity of environments } \\
\text { Image stores } \\
\text { Ambience sophistication } \\
\text { Securities } \\
\text { Temperature } \\
\text { Landscaping } \\
\text { Comfort }\end{array}$} & \multicolumn{2}{|c|}{$\begin{array}{l}\text { Culture, Convenience, Recrea- } \\
\text { tional, Commercial, Services }\end{array}$} \\
\hline 离 & $\begin{array}{l}\text { Emotional state } \\
\text { Emotional } \\
\text { motives } \\
\text { Security } \\
\text { Status } \\
\text { Exclusivity } \\
\text { Practicality } \\
\text { Comfort }\end{array}$ & & 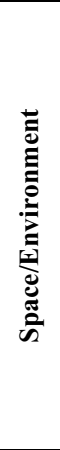 & $\begin{array}{l}\text { Lighting } \\
\text { Signaling } \\
\text { Temperature } \\
\text { Floor } \\
\text { Ramps and lifts } \\
\text { Handrails } \\
\text { Automatic doors, } \\
\text { Size of runners } \\
\text { Demarcation of } \\
\text { access and gaps }\end{array}$ & & 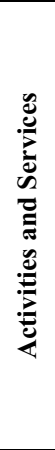 & $\begin{array}{l}\text { Stores } \\
\text { Clinics } \\
\text { Food courts } \\
\text { Cinemas } \\
\text { Children plays areas } \\
\text { Interactive entertain-ment } \\
\text { Social use areas } \\
\text { Relaxation Spaces } \\
\text { Cultural spaces } \\
\text { Promotional areas } \\
\text { Supermarkets } \\
\text { Assistance in transporting } \\
\text { purchases } \\
\text { Buses and taxis }\end{array}$ \\
\hline
\end{tabular}




\section{Discussion}

From the theoretical survey conducted and organizated in Table 1, according to the authors, the parameters or attributes identified in the study of usability, consider subjective aspects related to psychological, cognitive, and social the elderly. The objective aspects, are mostly related to the biophysiological issues. About attractiveness attributes for the spaces of shopping centers, present in Table 2, these are configured in much the same way on the spatial qualities, as well as those needs are the result of the users in relation to shopping. The objetives and subjective aspects present in the relationship between man-space, resulting from research on user expectations about the shopping malls. In both cases, usability and attractiveness are linked by the biophysiological demands, and physical spaces they need for their implementation.

Thus, Table 3 presents a summary, (on top, and at the bottom) of all the aspects studied, the complementarity and proposes, (in the center of the table), ways on how the study can address the demands of the elderly.

Table 3

Organization of the grid attributes usually with a demonstration of the relationship between attractiveness and usability of the elderly biopsychosocial changes

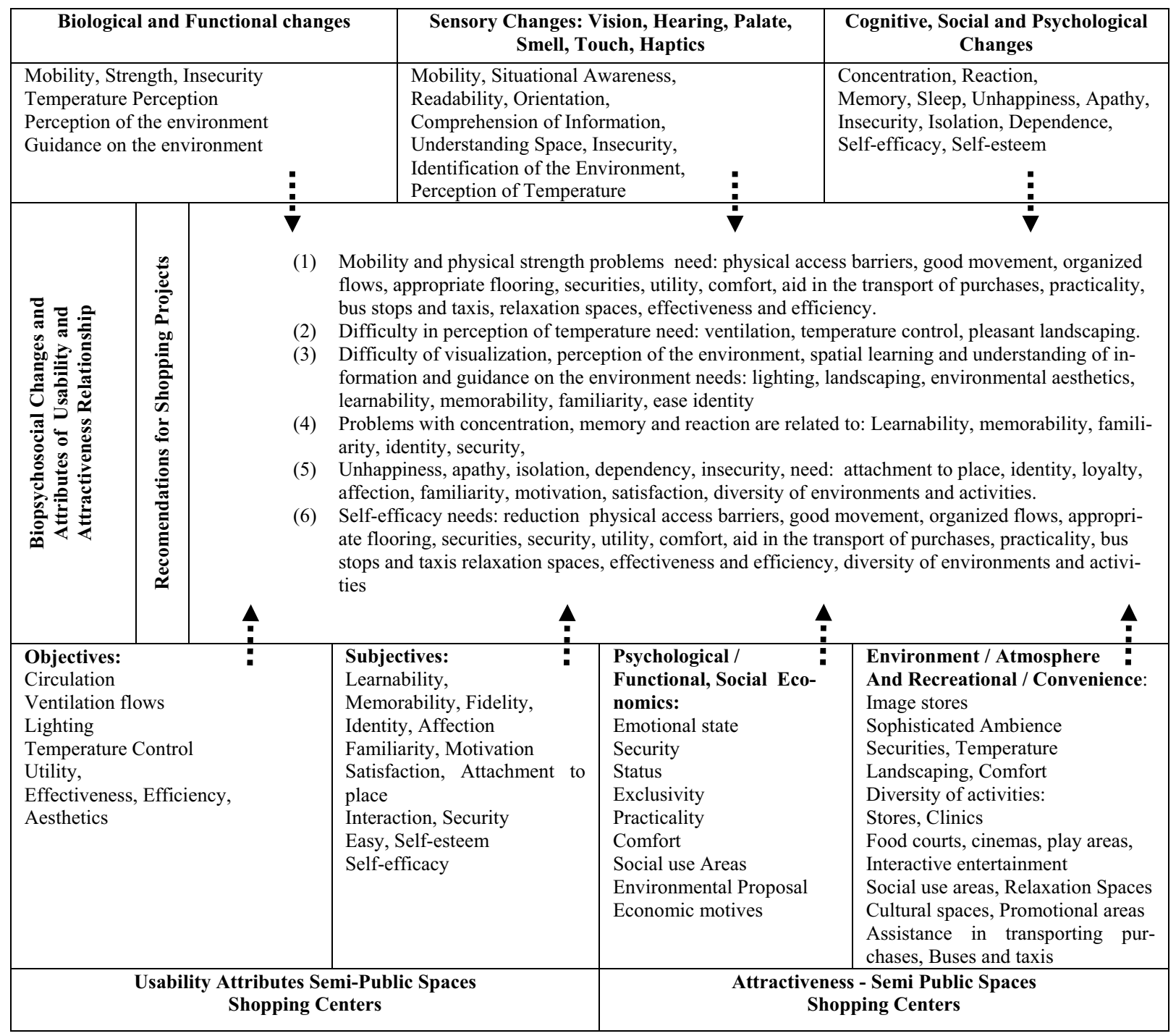




\section{Conclusion}

To study the environmental perception and behavior is critical to better understand the interrelationships between man and the natural or built environment, their expectations, judgments and lead-ing, since the results of architectural projects, and human interference in the environment may affect the quality of life and well-being. The study of this relationship is essentially a multidisciplinary field.

The concept of aging come escalate into and beyond the chronological age. The person conditions must be evaluated also by the quality of elapsed time. Even so, the consequences of the aging process affect the relationship with the environment and the elderly causing limitations to its use and integration with others.

The survey found that through the study of usability space added to the study of bio-physiological alterations, and social of elderly users, the projects of built spaces can predict and meet the space requirements in order to optimize physical and cognitive users abilities .

The choice of the theme "Shopping Centers", directs the search for a current focus in ambient that are now very used buy the elderly, considering the functionality, comfortability, safety, among others, and the study of the attractiveness attributes should helped towards understanding the users expectations in relation to the shopping environments, checking that they do not relate only to physical spaces themselves, but the number and quality of activities, services, and humanization of care.

So, attend environments which provide easy access to services and activities, displacements safe and enjoyable, as well as social integration, can enrich perceptual experience and spatial mobility, autonomy, self-efficacy and self-esteem, helping the connection of elderly with the world through an active life and social participation in this important phase of life.

The sum of the three axes of research: biopsychosocial issues, usability and attractiveness resulted in a general plan of recommendations from the association between needs and expectations of the elderly, overall space constraints, and attributes considered important by the users for enterprises Shopping Centers. It was verified the importance of the multidisciplinary study of the check from the close relationship between the three axes of research.

The work does not exhaust the knowledge existing in the area, but to deepen it, on the understanding the perception, use and satisfaction for the elderly in spaces, in order to meet the demands of the aging population and generate grants, assist future scientific research, technical papers related to the production and evaluation in the built in general.

\section{References}

[1] A.L. Neri, Contribuições da Psicologia ao Estudo da Intervenção no Campo da Velhice. Revista Brasileira de Ciências do Envelhecimento Humano, p.p 69-80, Passo Fundo, 2004.

[2] Abrasce, Associação Brasileira de Shopping Centers, 2010, http://www.portaldoshopping.com.br/

[3] A. de Moraes, C. Melo, V. L. Puerari, Ergonomia e Usabilidade: Acidentes com Idosos no Ambiente Doméstico, PUC, Rio de Janeiro, 2003.

[4] A. Rapoport, Aspectos Humanos de La Forma Urbana, Editorial Gustavo Gilli, S.A., Barcelona, 1982.

[5] A.D. Fisk, W. A.Rogers, N. Charness, S. J.Cjaza, J.Sharit, Designing for Older Adults, Principal and Creative Human Factors Approaches, CRC Press, N.Y., 2009.

[6] B. Figueiredo, Arquitetura: Os novos Jardins de Lojas. Arcoweb-Revista Projeto Design. http://www.arcoweb.com.br/ acesso em 04/2010.

[7] Brasil, Organização Mundial da Saúde, OMS. Disponível em : HTTP://www.who.org/>

[8] C.D. Silva, O papel dos Shopping Centers na Formação de Clusters. O caso do Shopping Aricanduva na Cidade de São Paulo, Monografia, Escola Politécnica de São Paulo, SP, 2007.

[9] C.L. Souza, Cognição Ambiental e as Relações : Mapas Cognitivo, Ambiente Construído e A.P.O, UNB, Brasília, DF, Instituto de Psicologia Ambiental, 1995.

[10] D. Gallahue , J. Ozmun, Compreendendo o Desenvolvimento motor: bebês, crianças, adolescentes e adultos, Phorte, São Paulo, 2001 .

[11] D. E Papalia, S.O., Wenkdos, Desenvolvimento Humano, Artmed Editora S.A, Porto Alegre, 2006.

[12] E. Hall, T. Dimensão Oculta, Livraria Francisco Alves, Editora Ltda, 2a . Edição, Rio de Janeiro, 1981

[13] F. A. C., Lundberg, D. F. Campos, T.Souza, 2010, Atratividade de Shopping Centers: Uma Abordagem com o Público Jovem. Anais Simpoi, 2010.

[14] G.I. Zimmerman, Velhice: Aspectos Biopsicosociais, Artes Médicas, Porto Alegre, 2000.

[15] G.Z. Mazo, M. A. Lopes, T. B. Benedetti, Atividade física e o idoso: concepção gerontológica, Sulina, Porto Alegre, 2004.

[16] H.Frugoli Jr., Sociabilidade e consumo nos Shopping Centers de São Paulo: Eventos e Desafios Recentes In: Bueno; M; L. \& Camargo, L. O. (orgs). Cultura e Consumo: Estilos de Vida na Contemporaneidade. São Paulo, Ed. Senac S. Paulo, pp. 231-246.

[17] H. Gunther, G. Elali, J.Q. Pinheiro, Abordagem Multimétodos em Estudos Pessoa-Ambiente, em: Métodos de Pesquisa nos Estudos Pessoa Ambiente. All Books, Casa do Psicólogo, São Paulo, 2008.

[18] H. Hertzberger, Lições de Arquitetura, Editora Martins Fontes, Rio de Janeiro, 1999.

[19] H.L.R.; Valle, L. Zarebski, G., E. Valle, Neurociências na Melhor Idade, Aspectos Atuais em uma Visão Interdisciplinar, Editora Novo Conceito, Saúde. Ribeirão Preto, SP, 2009

[20] ISODIS 9241, International Organization for Standardization,(ISO)

http://en.wikipedia.org/wiki/ISO_9241\#ISO_9241-11, junho, 2010 [21] J. S. Dumas, J. C. \& Redish, (1999). A Practical Guide to Usability Testing, Intellect, 1999. 
[22] J.Q. Pinheiro, G. Elali, Métodos de Pesquisa em Estudos Pessoa Ambiente. Ed. All Books, Casa do Psicólogo, São Paulo/ SP. 1 ${ }^{\mathrm{a}}$. Edição, 2008.

[23] J.R.; Nevin, M.J. Houston, Image as a component of attraction to intra-urban shopping áreas, Journal of Retailing, v. 56, n. 1, 1980 .

[24] K., Lynch, A imagem da Cidade; The Image of The City. Massachusets Technology Institute, and Harward College, Tradução: Maria Cristina Tavares Affonso. Edições 70, Lisboa, Portugal; 1960

[25] K.M.Wong, L.Yu, Consumers Perception of Store Image of Joint Venture Shopping Centres: First-Tier versus Second Tier Cities in China, Journal of Retailing and Consumer Services, v.74, n.4, p.p. $61-70,2003$.

[26] K. Wakerfield, J. Baker, Excitement at the mall: determinants and effects on shopping response, Journal of Retailing, v. 74, n. 4 , 1998

[27] M. I. El-Adly, Shopping malls attractiveness: a Segmentation Approach. International Journal of Retail \& Distribution Management, v. 35, n. 11, 2007.

[28] M. Goyas, Vida Ativa na Melhor Idade. Revista da UFG, Vol. 5, No. 2, 2003.

[29] M.L. Mallard, As aparências em Arquitetura. Ed. UFMG, Belo Horizonte, MG, 2006.

[30] M. Sievert, Nova Geração de Idosos: um consumidor a ser conquistado. X Conferência Brasileira de Comunicação e Saúde, Universidade Metodista de São Paulo, São Paulo, 2007.

[31] Michaelis, Moderno Dicionário da Lingua Portuguesa on Line, http://michaelis.uol.com.br/, acesso em 06/06/2010.

[32] N. Bevan, Designing for Usability, HCI International, Munich, 22-26, 1999.

[33] N.S. Terblanche, The perceived benefits derived from visits to a super regional shopping centre: an exploratory study, South Africa Journal of Business Management, v. 30, n. 4

[34] ONU, Organização das Nações Unidas. Disponível em $<$ http://www.onuportugal.pt/onu.html. Acesso set/2010.

[35] P. Coleman, Shopping Environment, Evolution, Planning and Design, Architectural Press, Oxford, 2006

[36] P. Jordan, An Introdution to Usability, Taylor \&Francis, N.Y, 2002.

[37] P. Reingrantz, D. Alcantara, V. Del Rio, A influência do Projeto na Qualidade do Lugar. Sociedade e Território, Revista de Estudos Urbanos e Regionais. Dezembro- 2005, p.p 01-18.
[38] R. Donovan, J., Rossiter, G., Marcoolyn, A. Nesdale, Store atmosphere and purchasing behavior. Journal of Retailing, v. 70, n. 3, 1994 .

[39] R. J. Santos, Shopping Center, Comunicação e Cultura, Uma cidade dentro da Cidade, LCTE, Editora, São Paulo, 2010.

[40] R. Simões, Corporeidade e terceira idade. A marginalização do corpo idoso, Unimep, São Paulo, 1998.

[41] R. Sommer, Espaço Pessoal, as bases comportamentais de projetos e planejamento. São Paulo: EPU/ EDUSP, 1973

[42] R. J. Sternberg, Psicologia Cognitiva, Artes Médicas Sul, Porto Alegre, 2008.

[43] R. M. Moragas, Gerontologia Social, Envelhecimento e Qualidade de Vida. Editorial Herder, Barcelona, 1991.

[44] S. Ornstein, G. Bruna, M. Romero, Ambiente Construído \& Comportamento, Avaliação Pós-Ocupação e Qualidade Ambiental. Studio Nobel, USP, São Paulo, 1995.

[45] S. M. M. Matsudo, Envelhecimento, atividade física e saúde. Revista Mineira de Educação Física, Viçosa, v. 10, pp. 193-207, 2002.

[46] S. M. M. Matsudo, Envelhecimento e Atividade Física, v. 8, Midiograf, Londrina, 2001.

[47] U. A. Yavas, A multi-attributes approach to understanding shopper segments, International Journal of Retail \& Distribution Management, v. 31, n. 11, 2003

[48] V. Del Rio, C. Duarte, R., A. Rheingrantz, Projeto do lugar: colaboração entre psicologia, arquitetura e urbanismo. Rio de Janeiro, 2002.

[49] V. Jackson, Stoel, L. \& Brantley, A. (2011). Mall attributes and Shopping Value: Differences by Gender and Generational Cohort. Journal of Retailing \& Consumer Services, v.18, I. 3, May 2011 .

[50] W. Lidwell, K.Holden, J. Butler, Universal Principals of Design, Rockport Publishers, Massachusetts, 2003.

[51] W. Preiser, Post-Occupancy Evaluation, Van Nostrand Reinhold, N.Y.,1987.

[52] Y. Afacan, C. Erbug, An interdisciplinary Heuristic Evaluation Method for Universal Building Design Applied Ergonomics 40 p.p. $731-744,2009$.

[53] Y. Morigushi, E. A. J. Neto, Biologia Geriátrica. Edipucrs, Porto Alegre, 2003.

[54] Y.F. Tuan, Images and Mental Maps. Annals of the Association of American Geographers, vol 65, no. 02, p.1-9, june1975. 